KEMAS 16 (2) (2020) 163-168
Jttp://journal.unnes.ac.id/nju/index.php/kemas

\title{
SBAR (Situation, Background, Assessment, Recomendation) Communication on Attitude And Nursing Behavior in Improving Patient Safety
}

\author{
Sukesih ${ }^{\bowtie}$, Umi Faridah \\ Universitas Muhammadiyah Kudus, Kudus, Indonesia
}

\begin{tabular}{l} 
Article Info \\
\hline Article History: \\
Submitted September 2018 \\
Accepted April 2020 \\
Published November 2020 \\
\hline Keywords: \\
SBAR; Behavioral \\
Attitudes, Patient Safety \\
\hline DOI \\
https://doi.org/10.15294/ \\
kemas.v16i2.15954
\end{tabular}

\begin{abstract}
SBAR (Situation, Backgroud, Assessment, Recomendation) communication is an information tool that provides a structured or systematic method that facilitates communication between health workers. SBAR communication is easy because communication has been systematically structured to report the condition of patients to other health workers so as to improve patient safety by reducing errors that occur during the action. The purpose of this study was to determine the effect of SBAR communication on nurses' attitudes and behavior in improving patient safety. The type of research used was quasi experiment with pre-posttest with control group design, the results of the study were processed by paired sample $t$ test and independent samples $t$ test, SBAR communication instruments using observation, attitude and behavior instruments of nurses using questionnaires. The population in the study of all nurses who served in the inpatient room is ivory 1, ivory 2, flamboyant, dahliah RAA Soewondo Pati Hospital as many as 48 nurses, the sampling technique in the study was a total sampling of 48 nurses. There was a significant difference in nurses' attitudes after being given SBAR communication training in the intervention group with a p value of 0,000 compared to the control group with a $\mathrm{p}$ value of 0.103 . There was a significant difference in the nurses' behavior after being given SBAR communication training in the intervention group with a $\mathrm{p}$ value of 0,000 compared to the control group with a p value of 0.198 .
\end{abstract}

\section{Introduction}

Patient safety is the spirit of hospital services around the world, not only in developed countries implement it to ensure good service quality, but also in developing countries like Indonesia (Field et al., 2011). The WHO Collaborating Center for Patient Safety on May 22007 officially published the "Nine Life Saving Patient Safety Solution". This guide was developed in 2005 by patient safety experts and more than 100 countries by identifying and studying various patient safety problems. With the publication of Nine Life Saving Patient Safety by WHO, the Hospital Patient Safety Committee (KKP-RS) encourages hospitals in Indonesia to implement Nine "Life-Saving" Solutions for hospital patient safety, directly or gradually according to the capabilities and conditions of the hospital. respectively, one of the nine solutions is to implement communication effectively during patient handover (Istanti, 2015).

Communication of hand-over of patients between nurses and among health care workers sometimes does not include important information or the information provided is inaccurate and difficult to understand, resulting in gaps in communication that can cause misinterpretation or misunderstanding other than that it can result in disconnection of continuity of service, inappropriate treatment and can potentially result in injury to the patient, so an approach is needed to facilitate systematic patient handover (Merten, 
Lubberding, Wagtendonk, Johannesma, \& Wagner, 2011). This is aimed at improving the attitudes and behavior of nurses during patient handover, including the use of procedures in communicating critical information, providing opportunities for nurses to ask and submit questions during handover and involve patients and families in the handover process (Care et al., 2010).

Attitudes and behavior of nurses in providing nursing care to patients must implement patient safety, nurses must involve cognitive, affective, and actions that prioritize patient safety (Sudiharti, 2012). Attitudes and behaviors of nurses who do not maintain patient safety contribute to patient safety incidents. One solution to improve patient safety is by effective communication on nurses' attitudes and behavior (Kesrianti, Bahry, \& Maidin, 2015).

Proper communication with read back has become one of the goals of patient safety programs, namely increasing effective communication during handover, one of the effective communication methods during handover is SBAR communication (Chaharsoughi, Ahrari, \& Alikhah, 2014). SBAR communication (Situation, Backgroud, Assessment, Recommendation) is an information tool that provides a structured and formal method of communication between staff, communication methods that originate in the aviation and military industries and have been adapted for use in health care, in clinical settings SBAR has the potential to improve staff's ability to compile and convey critical information, increase staff's ability to receive and interpret critical information and improve patient safety by reducing errors that occur during actions (Susan M. Renz, DNP, RN et al., 2014).

Research conducted by Wahyuni (2014) shows S-BAR communication training is effective in improving the quality of over shift in Wardah ward Unit II PKU Muhammadiyah Hospital Yogyakarta, this shows that effective SBAR communication involves health workers, patients and families according to their conditions can help in communication, both individuals and teams who can ultimately influence changes in improving the quality of shift operations and improving patient safety, so that there is a positive impact and there is an apparent improvement in the reporting of patient safety incidents (Wahyuni.R, 2014).

Another study on SBAR communication is one conducted by Fitria (2013) regarding SBAR communication training in increasing nurses' motivation and psychomotor. The research objective is to analyze the effectiveness of SBAR communication training in increasing motivation and psychomotor nurses in medical surgical treatment rooms. In this study, it was reported that there were new findings that SBAR communication could increase the motivation and psychomotor of nurses, this could affect the performance of nurses and could improve the work culture of nurses in carrying out nursing care so that it could improve patient safety (Fitria, C., 2013)

According to Cunningham, (2012) SBAR communication can improve telephone communication between nurses and doctors by using the SBAR tool that is structured and accurate so that problems can be evaluated and communicated clearly and well, also improve patient safety. The research objective was to determine the effect of SBAR communication on nurses' attitudes and behavior in improving patient safety. (Cunningham et al., 2012) Background, Assessment, Recommendation (SBAR).

\section{Method}

This research is a quasi experimental study with a pretest-posttest design with control group design, the results of the research were processed by using paired sample $t$ test for related samples and independent samples $t$ test for unrelated samples to analyze nurses' attitudes and behavior in improving patient safety. after being given the SBAR communication intervention, the over shift time was morning shift, afternoon shift, night shift. The population in this study were all nurses who served in the inpatient room class 3 , namely the ivory room 1 , the ivory room 2 , the flamboyant room, the dahlia room at RAA Soewondo Pati Hospital as many as 48 nurses, the sampling technique in this study was the total sampling, the number of samples was 48 nurses divided into the intervention group in the ivory room 1 and the ivory room 2 were 
24 nurses, the control group in the flamboyant room and the dahlia room were 24 nurses with inclusion criteria: D3 education, treatment nurses, not on leave, willing to be respondents, exclusion criteria: S1 education, head of the room / nurse coordinator, intern nurse, student nurse, research was conducted from April to May 2018

The data collection of this research uses a checklist of observation sheets to assess the ability of nurses to communicate SBAR, attitudes and behavior of nurses using a questionnaire. SBAR communication steps between nurses in reporting the patient's condition at each change of duty (over shift) include:

$S$ (Situation): I will inform you about the patient: Name: Mrs. S Age: 70 years Sex: female RM No: 123456 Medical diagnosis: hypertension

B (Background) Main complaints: dizziness, history of current illness: for 2 days the patient complained of dizziness then bought medicine at the pharmacy but there was no change after that the patient was taken to the emergency room of the hospital, the results of blood pressure checks were 190/100 $\mathrm{mmHg}$, temperature $36^{\circ} \mathrm{C}$ pulse $88 \mathrm{x} /$ minute breaths $22 \mathrm{x} /$ minute, the patient is given an injection and is put in an infusion then entered the inpatient room. Past medical history: the patient does not have a hereditary disease such as diabetes mellitus, heart disease family history: the family does not have hereditary diseases such as diabetes, heart disease history of allergies: the patient does not have allergies to medications, food, drinks and others

A (Assessment) The general condition of the patient: limp, blood pressure 190/100 mmHg temperature $36^{\circ} \mathrm{C}$ pulse $88 \mathrm{x} /$ minute breath 22x / minute GCS: 15, Patient not using oxygen IV fluid: RL 20 drops / minute.

$\mathrm{R}$ (Recommendation) Actions that have been taken: administration of anti-hypertensive drugs Discontinued action: no action is stopped Actions that are continued: administration of anti-hypertensive medicines.

The checklist for SBAR communication skills uses an observation sheet about nurses' abilities during the implementation of SBAR communication. The observation sheet is in the form of a checklist containing a list of statements about the attitudes and behavior of nurses during the implementation of the SBAR communication which is compiled based on the SBAR communication tool with the choice of answers being made and not carried out with 15 statement items consisting of situation, background, assessment, and recommendation. The statement has 2 answers, namely the value of 1 is carried out and the value of 0 is not carried out. The lowest score is 0 and the highest score is 15 . The score of nurses' attitudes and behavior is measured from the response to 10 items using a 5 point likert scale, namely a score of 1 (strongly disagree), a score of 2 (disagree), a score of 3 (neutral), a score of 4 (agree), and a score of 5 (strongly agree) The SBAR communication instrument uses the content validity test by asking for expert opinion and reliability by using the cohen's kappa coefficient test to assess the consistency of the observation sheet in this study. The results of the kappa test show an agreement between observer 1 and observer 2 which is indicated by a $p$ value of $0.0025<0.05$ with a kappa value of 1.0 which means special (unanimous agreement). The attitude and behavior instrument of nurses used the validity test with $\mathrm{r}$ count attitude (0.812$0.960), r$ count behavior (0.809-0.980) while $r$ table (0.631) which means that the attitude and behavior questionnaire was declared valid because $r$ count $>r$ table. While the attitude reliability test $(0.560-0.645)$, the value of Cronbach's alpha is 0.555 , which means that all attitude statement items are declared reliable, while the behavior questionnaire has a value (0.583-0.673), the value of Cronbach's alpha is 0.512 , which means that all behavior statement items are declared reliable.

\section{Result and Discussion}

The results of the study obtained data on the characteristics of participants, namely age, gender, and years of service. The number of samples in the study were 48 nurses consisting of 24 nurses as the intervention group and 24 nurses as the control group.

Comparison of nurses' attitudes before and after being given SBAR training in the intervention group and the control group Comparison of the behavior of nurses before and after being given SBAR training in the intervention group and the control group. 
Table 1. Comparison of researched sample characteristics between intervention group and control group

\begin{tabular}{|c|c|c|c|c|c|}
\hline \multirow[b]{2}{*}{ No } & \multirow[b]{2}{*}{ Variable } & \multicolumn{2}{|l|}{ Average \pm SD } & \multirow{2}{*}{$\begin{array}{l}\text { Total } \\
(\mathrm{n}=48)\end{array}$} & \multirow[t]{2}{*}{$\mathrm{P}$ value } \\
\hline & & Intervention & Control & & \\
\hline \multirow[t]{3}{*}{1} & Age & & & & \\
\hline & Mean & $29,58 \pm 5,85$ & $28,08 \pm 5,37$ & - & 0,446 \\
\hline & Min - Max & $24-42$ & $23-41$ & - & \\
\hline \multirow[t]{3}{*}{2} & Year of service & & & & \\
\hline & Mean & $3,54 \pm 2.91$ & $3,38 \pm 2,81$ & - & 0,218 \\
\hline & Min - Max & $1-11$ & $1-11$ & - & \\
\hline \multirow[t]{3}{*}{3} & Gender & & & & \\
\hline & Male & 8 & 9 & 17 & 0,201 \\
\hline & Female & 16 & 15 & 31 & \\
\hline
\end{tabular}

Table 2. Comparison of nurse attitude before and after SBAR training on intervention group and control group

\begin{tabular}{llll}
\hline Nurse Attitude & Average \pm SD & P value $\left(^{*}\right)$ \\
\cline { 2 - 3 } & $\begin{array}{l}\text { Intervention } \\
(\mathrm{n}=24)\end{array}$ & $\begin{array}{l}\text { Control } \\
(\mathrm{n}=24)\end{array}$ \\
\hline Before training & $18,16 \pm 5,52$ & $18,12 \pm 5,51$ & 0,979 \\
After training & $29,12 \pm 6,73$ & $20,08 \pm 5,66$ & $0,000^{*}$ \\
P value ${ }^{* *}$ & $0,000^{* *}$ & 0,103 & \\
\hline
\end{tabular}

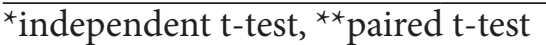

Tabel 3. Comparison of nurse behavior before and after SBAR training on the intervention group and the control group

\begin{tabular}{llll}
\hline Nurse Behavior & Average \pm SD & P value $\left(^{*}\right)$ \\
\cline { 2 - 3 } & $\begin{array}{l}\text { Intervention } \\
(\mathrm{n}=24)\end{array}$ & $\begin{array}{l}\text { Control } \\
(\mathrm{n}=24)\end{array}$ \\
\hline Before training & $18,41 \pm 5,23$ & $18,12 \pm 5,51$ & 0,979 \\
After Training & $27,91 \pm 6,31$ & $20,08 \pm 5,66$ & $0,000^{*}$ \\
$\mathrm{P}$ value $\left.{ }^{* *}\right)$ & $0,000^{* *}$ & 0,103 & \\
\hline
\end{tabular}

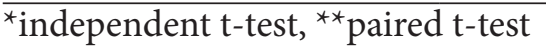

The results showed that before being given SBAR communication training in the intervention group and the control group there was no significant difference in the mean attitude of nurses $18.16 \pm 5.52$, there was a significant difference in the attitudes of nurses after being given SBAR communication training in the intervention group compared to the control group. This is indicated by the results of statistical tests with a $p$ value of 0.000 . There was no significant difference in the initial and final measurements of nurses' attitudes in the control group. This is indicated by the $\mathrm{p}$ value $>0.05$.
The results showed that there were significant differences in the attitudes of nurses in the intervention group before and after being given SBAR communication training as indicated by $\mathrm{p}$ value $<0.05$. The results of measuring the mean value of the intervention group increased from 18.16 to 30.12 after being given the SBAR training intervention.

Attitude is a reaction or response that is still covered from someone to a stimulus or object. Attitude manifestations cannot be immediately seen, but can only be directly interpreted in advance of closed behavior (Meutia, Yulianti, \& Info, 2019). Behavior is 
a person's response or reaction to a stimulus (external stimuli), thus human behavior occurs through a stimulus-organism-response process. Health behavior is a person's (organism) response to stimuli or objects related to illness or disease, the health service system, food and beverages, and the environment. (Rasyid, Thoyib, \& Indyanty WL, 2015).

This is aligned with the research conducted (Meester, Verspuy, Monsieurs, \& Bogaert, 2013) which states that SBAR communication is one example of collaboration between nurses and doctors where nurses and doctors have the same role, the use of standard SBAR communication frameworks in handover of patients can improve the nurse's ability to communicate. Meanwhile, Nazri's research stated that the role of doctors in receiving information and the willingness to respond to nurse communication is an important factor and can become an obstacle to the SBAR communication application if it is not achieved properly. (Meutia et al., 2019).

In line with research conducted by (Diniyah, 2017) stated that SBAR is a better modelbecauseit can beapplied to everysituation, as well as at patient handover. SBAR facilitates the formation of communication patterns in the system, and through recommendations or through final action will build the formation of collaboration in groups. Kasten also mentioned that SBAR training with the role play method for nursing students has benefits and changes their knowledge and communication skills for the better. (Sanitation, 2019).

\section{Conclussion}

Based on the statistical test, there were significant differences in the attitudes of nurses in the intervention group before and after being given SBAR communication training as indicated by $p$ value $<0.05$. The results of measuring the mean value of the intervention group increased from 18.16 to 30.12 after being given the SBAR training intervention. Further research is needed to assess the determinants of nurses' attitudes and behavior with different variables or interventions with a larger sample size. The research results are expected to be a reference for improving patient safety so as to improve the quality of good service in the hospital.

\section{Refrences}

Care, I., Boaro, N., Fancott, C., Baker, R., Velji, K., \& Andreoli, A. (2010). Using SBAR to improve communication in interprofessional rehabilitation teams, 24(January), 111-114. https://doi.org/10.3109/13561820902881601

Chaharsoughi, N. T., Ahrari, S., \& Alikhah, S. (2014). Comparison the Effect of Teaching of SBAR Technique with Role Play and Lecturing on Communication Skill of Nurses, 3(2), 141147. https://doi.org/10.5681/jcs.2014.015

Cunningham, N. J., Weiland, T. J., van Dijk, J., Paddle, P., Shilkofski, N., \& Cunningham, N. Y. (2012). Telephone referrals by junior doctors: A randomised controlled trial assessing the impact of SBAR in a simulated setting. Postgraduate Medical Journal, 88(1045), 619-626. https://doi.org/10.1136/ postgradmedj-2011-130719

Diniyah, K. (2017). Pengaruh Pelatihan SBAR RolePlay terhadap Skill Komunikasi Handover Mahasiswa Kebidanan, 6(1), 35-44. https:// doi.org/10.18196/jmmr.6125.Pengaruh

Field, T. S., Tjia, J., Mazor, K. M., Donovan, J. L., Kanaan, A. O., Harrold, L. R., ... Gurwitz, J. H. (2011). Randomized Trial of a Warfarin Communication Protocol for Nursing Homes : an SBAR-based Approach. AJM, 124(2), 179.e1-179.e7. https://doi. org/10.1016/j.amjmed.2010.09.017

Fitria, C., N. (2013). Efektifitas Pelatihan Komunikasi SBAR dalam Meningkatkan Motivasi dan Psikomotor Perawat di Ruang Medikal Bedah RS PKU Muhammadiyah Surakarta. Proceeding Seminar Dan Presentasi Poster Ilmiah Keperawatan "Adult Nursing Practiice: Using Evidence In Care" PSIK Fakultas Kedokteran Universitas Diponegoro, 135.

Kesrianti, A. M., Bahry, N., \& Maidin, A. (2015). Faktor-Faktor yang Mempengaruhi Komunikasi pada Saat Handover di Ruang Rawat Inap Rumah Sakit Universitas Hasanuddin, 13.

Meester, K. De, Verspuy, M., Monsieurs, K. G., \& Bogaert, P. Van. (2013). SBAR improves nurse-physician communication and reduces unexpected death: A pre and post intervention study. Resuscitation. https://doi. org/10.1016/j.resuscitation.2013.03.016

Merten, H., Lubberding, S., Wagtendonk, I. Van, Johannesma, P. C., \& Wagner, C. (2011). Patient safety in elderly hip fracture patients : design of a randomised controlled trial. BMC Health Services Research, 11(1), 59. https:// doi.org/10.1186/1472-6963-11-59

Meutia, I. F., Yulianti, D., \& Info, A. (2019). Jurnal 
Kesehatan Masyarakat, 15(2), 187-195.

Rasyid, H. Al, Thoyib, A., \& Indyanty WL, E. (2015). Pengaruh Pengetahuan, Sikap, dan Perilaku Perawat tentang Flebotomi terhadap Kualitas Spesimen Laboratorium The Influence of Nurses ' Knowledge, Attitude, and Behavior over Phlebotomy on Laboratory, 28(3), 258262.

Sanitation, E. (2019). Jurnal Kesehatan Masyarakat, 15(2), 171-178.

Sudiharti, S. (2012). Hubungan pengetahuan dan sikap dengan perilaku perawat dalam pembuangan sampah medis di rumah sakit pku muhammadiyah yogyakarta. Jurnal
Kesehatan Masyarakat, 6(1), 49-59.

Susan M. Renz, DNP, RN, G.-B., A, Marie P. Boltz, $\mathrm{PhD}, \mathrm{RN}, \mathrm{G} .-\mathrm{B} ., \mathrm{B}$, Wagner, Laura M.PhD, R., C, ... Thomas E. Lawrence, M. (2014). NIH Public Access, 34(4), 295-301. https:// doi.org/10.1016/j.gerinurse.2013.04.010. Examining

Wahyuni.R. (2014). Efektifitas pelatihan komunikasi S-BAR dalam meningkatkan mutu operan jaga (handover) di bangsal wardah RS PKU Muhammadiyah Yokyakarta Unit II. Universitas Muhammadiyah Yogyakarta. 